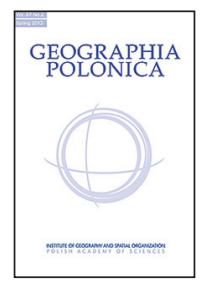

\title{
HEAT- AND COLD-RELATED MORTALITY IN THE NORTH-EAST OF POLAND AS AN EXAMPLE OF THE SOCIO-ECONOMIC EFFECTS OF EXTREME HYDROMETEOROLOGICAL EVENTS IN THE POLISH LOWLAND
}

\author{
MAGDALENA KUCHCIK, MAREK DEGÓRSKI \\ Insitute of Geography and Spatial Organization, \\ Polish Academy of Sciences, \\ Twarda 51/55, 00-818 Warsaw, Poland \\ E-mails: mkuchcik@twarda.pan.pl; m.degor@twarda.pan.pl
}

\begin{abstract}
This article looks at certain socioeconomic consequences of extreme hydrometeorological phenomena in the Polish Lowland, e.g. floods, droughts, hurricanes, heat and cold waves that have all become more intense in Poland over recent years. The particular focus is on the impact of extreme high temperature and severe cold events on socio-medical parameters such as mortality. The analysis is especially concerned with increased daily numbers of deaths in 3 large urban centers located in northeast Poland.
\end{abstract}

Key words: extreme hydrometeorological phenomena, heat waves, cold waves, human mortality, Polish Lowland

\section{INTRODUCTION}

Changes in temperature are considered the main exogenous factor responsible for disturbances in functioning of the environmental megasystem, be this the natural environment or the anthropogenic. Leaving aside the ongoing dispute between scientists as regards the causes of climate change and the prediction of further changes in successive centuries of the third millennium, the indisputable fact remains that the overall temperature increase from $1850-1899$ to $2001-2005$ is of $0.76^{\circ} \mathrm{C}$, while the global linear warming trend over the last 50 years is of $0.13^{\circ} \mathrm{C}$ (from 0.10 to $0.16^{\circ} \mathrm{C}$ per decade) (IPCC 2007). The regions affected most markedly have been at mid and high latitudes, not least in the Arctic and in Europe. Since 1950, Central Europe has been subject to statistically significant upward trends for maximum temperatures, as well as a small and non-significant decrease in cold weather indexes. In Poland, for each successive 10-year period: the maximum air temperature rose by $0.1-0.2^{\circ} \mathrm{C}$; the index for the duration of warm spells in turn revealed a lengthening of 2-3 days, while a non-significant decrease in the index for the duration of cold spells is also to be noted (ECA\&D; Przybylak et al. 2006).

Extreme weather impacts not only upon the environment, but also upon human beings. And among extreme weather phenomena the most frequent in Poland are heat waves and cold waves, which are associated with a great increase in morbidity and mortality rates. This is why they prove more dangerous to people than any other weather events, on account of their widespread and relatively frequent occurrence, especially in highlypopulated areas. In Poland, as in Europe as 
a whole, the number of heat waves has increased in recent decades. And, as the global climate continues to warm, the number and intensity of heat waves and the death tolls they give rise to might increase considerably. One example of such a situation was provided by summer 1994, which brought severe heat in Central Europe and the Benelux, lasting with some breaks from 26th June to 7th August (Sartor et al. 1995, Kyselý 2004). July 1994 was one of the hottest months ever noted in Poland (Kuchcik 2006).

During another summer, that of 2003, both Western and Southern Europe were plagued by a record heat wave extending from northern Spain to the Czech Republic, and from Germany to Italy. It raised summer temperatures to levels 20 to $30 \%$ above the seasonal average and repeatedly produced maxima in the range 35 to $40^{\circ} \mathrm{C}$. At least 35,000 people died as a result of this heat wave in Europe, though with France suffering the worst losses (of more than 14,000 deaths, especially among the very old - Kosatsky 2005). Such extreme weather conditions also have far-reaching adverse environmental effects on aquatic ecosystems and glaciers, as well as destroying crops and large areas of forest by way of the fire they promote. The financial losses resulting from Europe's 2003 heatwave are estimated to have exceeded 13 billion euros (UNEP 2004).

Summer 2003 in Poland was within the norm - unlike July 2006, which was the hottest month recorded in almost 230 years of archives (notwithstanding the fact that absolute temperature records set in 1994 were not broken). The heat wave lasted almost 6 weeks. On most days of that month the maximum air temperature exceeded $30^{\circ} \mathrm{C}$ and minimum $20^{\circ} \mathrm{C}$. Mean monthly air temperature was of $5^{\circ} \mathrm{C}$ higher above normal and reached $23,5^{\circ} \mathrm{C}$ in Poznań or $23,1^{\circ} \mathrm{C}$ in Warsaw. July 2006 was the warmest-ever month on record also for the Netherlands, Germany, Denmark, the United Kingdom and south Sweden, though little was said about victims of this heat wave - perhaps because it happened in July and not in August - the typical holiday month for most European countries.
Recent years have brought an intensification of other phenomena attesting to a transforming climate, like floods, droughts and severe gales. While there has been no significant rise in the total number of flood or gale events, the intensities of those that do arise are greater, attesting to climatic changes at the end of the 20th century and beginning of the 21 st that are qualitatively different - in terms of both rate and intensity - from those that took place previously.

However the aim of this article has thus been to assess the influence of extreme cold and hot weather especially on mortality in the chosen part of Poland, as well as to present some other socioeconomic outcomes of extreme climatic phenomena in the Polish Lowland.

\section{MATERIAL AND METHODS}

When it came to the socioeconomic consequences provoked by the out-of-theordinary atmospheric phenomena afflicting Poland over the last 10-20 years the first step in the analysis was the collection of existing data. This was particularly the case for flooding - including the 1997 "flood of the century", gales (peaking at the one which occurred in 2002), droughts, hailstorms and snow-blizzards.

To delimit heat and cold waves, daily meteorological data and mortality characteristics (general and cardiovascular mortality among people aged $\geq 65$ ) were collected for selected towns and cities in the Polish Lowland: Bialystok, Olsztyn and Warsaw (Fig. 1). Hourly meteorological data cover the 10year period 1993-2002, but the analysis of mortality was carried out for the two shorter periods 1993-1996 and 1999-2002, the break in the years 1997-1998 reflecting industrial action on the part of doctors, who refused to give causes of death.

Heat and cold waves have been defined using the following definition. A heat wave is a period lasting a minimum of 6 days ( 5 days where the start is in May or June) with 
an apparent temperature calculated for 12 UTC above the 95th annual percentile, and an increase of $2^{\circ} \mathrm{C}$ compared to the previous day. In the permissible 1-day breaks the apparent temperature may not drop below the 90th percentile.

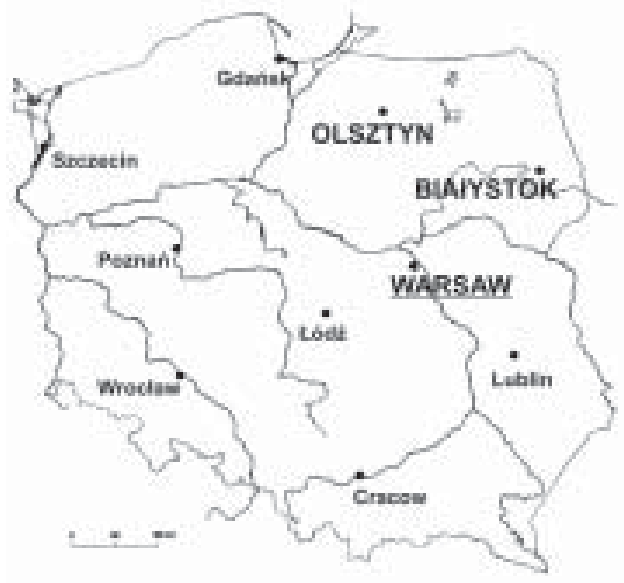

Figure 1. Contour map of Poland.

The formula of the apparent temperature is a simplified algorithm compared to the first one evaluated by R.G. Steadman (1984). It uses only two commonly measured inputs, of air temperature and dew point temperature (Kalkstein and Valimont 1986, Michelozzi et al. 2004). Assuming no wind or a light wind, it is given by:

$$
\mathrm{AT}=-2.653+0.994 \mathrm{~T}+0.0153(T d)^{2}
$$

where: $T$ - dry bulb temperature $\left({ }^{\circ} \mathrm{C}\right)$, $T d$ - dew point temperature $\left({ }^{\circ} \mathrm{C}\right)$.

A cold wave is regarded as a period lasting a minimum of 6 days with a daily minimum air temperature and mean daily air temperature below the 5 th annual percentile, and a decrease of $2^{\circ} \mathrm{C}$ compared to the previous day. In the possible 1-day break the minimum air temperature and mean daily temperature cannot exceed the 10th percentile (Kozłowska-Szczęsna et al. 2004).

The values of respective percentiles of apparent temperature and minimum and mean daily air temperature are:

\begin{tabular}{lcccccc}
\hline & \multicolumn{2}{c}{ app. temp. } & $\mathrm{t}_{\text {min }}\left[{ }^{\circ} \mathrm{C}\right]$ & \multicolumn{2}{c}{$\mathrm{t}_{\text {mean }}\left[{ }^{\circ} \mathrm{C}\right]$} \\
& \multicolumn{2}{c}{$\left[{ }^{\circ} \mathrm{C}\right]$} & \multicolumn{2}{c}{} & & \\
& 95 th & 90 th & 5th & 10th & 5th & 10th \\
\hline Bialystok & 26.2 & 23.6 & -11.1 & -7.1 & -6.9 & -3.8 \\
Olsztyn & 25.4 & 23.0 & -9.6 & -5.8 & -5.8 & -2.9 \\
Warsaw & 26.8 & 24.2 & -8.8 & -5.4 & -5.4 & -2.6 \\
\hline
\end{tabular}

In defining heat and cold waves the relative thresholds (e.g. the 95th percentile of apparent temperature) were used to include the important issue of human adaptation to climatic conditions. The climatic differences between Bialystok, Olsztyn and Warsaw varied greatly, even though the cities are relatively close together geographically.

Next, using generalized additive models for each city and each cause of death it was possible to devise a unique statistical model describing the dependence of mortality upon weather conditions, as well as longterm and seasonal changes in mortality. In this way a predicted number of deaths was obtained. Determined then was the relative death risk $(\mathrm{RR})$ - the rate of deaths in a particular weather situation compared with the numbers of deaths on days with reference atmospheric conditions in each city, presented also as the percentage rise or fall in predicted numbers of deaths.

$\mathrm{RR}=$ number of deaths on days within heat and cold waves / number of deaths on days with no heat or cold waves

The relative risk of death and $95 \%$ confidence intervals were calculated. If the value " 1 " was not in the range of the confidence interval, it was concluded that there was an increased or decreased risk on specific days compared to the non-specific days.

\section{RESULTS}

Poland's greatest ecological disasters caused by extreme hydrothermic phenomena took place in 1997 and 2002. Huge material losses resulted from them. The first of the events involved flooding on a scale unprecedented in the 20th century. Between 5 and 9 July 1997 rainfall in some parts of the Sudeten Mountains reached 450-480 mm, ex- 
ceeding the monthly average by $200 \%$. Maximum daily rainfall reached $200 \mathrm{~mm}$. The water lever in Klodzko rose from $100 \mathrm{~cm}$ on 4 July to $655 \mathrm{~cm}$ on 8 July, i.e. $70 \mathrm{~cm}$ higher than ever noted previously. The freshet in the Odra river basin appeared very fast, in some places only 9 hours past between the maximum rainfall and the culmination of the river water level. The then material losses exceeded 9.7 bn PLN (3.2 bn USD), though were markedly greater in the west of the country. There was also massive harm done to residential and road infrastructure, extending to 50,000 residential, commercial and public buildings, $6500 \mathrm{~km}$ of roads and railway lines, 1700 bridges and viaducts, and thousands of hectares of cropland and grasslands. The flood caused 54 deaths, and necessitated the evacuation of more than 106,000 people from flooded or threatened areas.

The gale of 2002, which affected NE Poland, was in turn the cause of destruction of c. 10,000 ha of forest. On 4 July 2002, a hurricane of momentary speed $170 \mathrm{~km} / \mathrm{h}$ lasted only for 15-20 minutes but devastated a belt of forest $130 \mathrm{~km}$ long and $15 \mathrm{~km}$ wide. The hurricane caused 13 injuries and over 500 cases of damage to buildings and power lines. A single Forest District (that of Pisz) sustained losses over more than 4000 ha of forest, with more than $1.4 \mathrm{~m} . \mathrm{m}^{3}$ of timber being laid flat. Work to rectify the damage done then continues to this day. Ever stronger winds mean ever greater economic losses to both housing stock and agricultural and forest output. Greater damage also means greater difficulty with extracting raw materials, and hence increased production costs. a more recent and more severe example of extreme wind was noted on 21st August 2007. A huge supercell was moved from the south-east of Poland to the north-east. Above the Mazurian Lakes it developed, the air temperature dropped from $28^{\circ} \mathrm{C}$ to $16^{\circ} \mathrm{C}$ and wind velocity suddenly increased to $35 \mathrm{~m} / \mathrm{s}$, causing a white squall. This storm caused 12 deaths among those sailing on the lakes.

Another cause of disruption to the proper functioning of forest and agricultural ecosystems is the intensifying drought phenomenon in the Polish Lowland. Such events remained a rarity in decades gone by, and were confined to 10-20 days in spring or summer, if they occurred at all (Degórski 1990). Improper hygrothermal relations resulting in shortfalls in soil humidity where the proper growth of vegetation is concerned, are characteristic of ever longer periods during the year. They have readily-identifiable ecological and economic consequences, e.g. intensifying fires. One of the severe droughts of recent decades affected Poland in 2006. In the west of the country July rainfall reached about $10 \mathrm{~mm}$ while normally it is $70-80 \mathrm{~mm}$. 6 weeks of heat almost without rain resulted in a drought that started in June and in July and in many places became hydrological drought - the last and most dangerous stage.

Floods, droughts and gales induce huge socio-economic losses and take lives. Despite the fact they have occurred more often in recent years they are still sporadic hydrometeorological phenomena. More common and more frequent among the extreme weather events, though still taking many lives, are the heat and cold waves.

The climate in Poland changes from a milder one under maritime influences in the west through to a more severe, continental one in the north-east. Annual mean air temperatures vary from $7.4^{\circ} \mathrm{C}$ in Bialystok (the north-east), via $8.4^{\circ} \mathrm{C}$ in Warsaw to $9.2^{\circ} \mathrm{C}$ in Wroclaw (south-west). The north-east area, which was studied, represents the coldest part of Poland and includes three specific cities: 1) the capital Warsaw, which is the largest city in Poland with the highest standard of living, the highest average salary, the least number of persons per dwelling and a negative natural increase meaning that more people die than are born. 2) Bialystok which is the "coldest" of the big cities among those with at least 100,000 inhabitants, with a high unemployment rate (13.3\%) and low monthly salaries. 3) Olsztyn is the "healthiest" city. It has low pollution levels, with a milder climate than Bialystok and with one of Poland's lowest mortality rates (6.7 deaths per thousand). 
Table 1. General air temperature and population characteristics of the 3 analyzed cities.

\begin{tabular}{cccccccc}
\hline & $\begin{array}{c}\mathrm{t}_{\max } / \mathrm{t}_{\min } \\
\mathrm{t}_{\text {mean* }}\end{array}$ & \multicolumn{4}{c}{2002} & & \multicolumn{2}{c}{ daily no. of deaths** } \\
\cline { 3 - 7 }$\left[{ }^{\circ} \mathrm{C}\right]$ & population & $\begin{array}{c}\text { death/100 } \\
\text { inhabitants }\end{array}$ & $\begin{array}{c}\text { rate of } \\
\text { natural } \\
\text { increase }\end{array}$ & all & all $\geq 65$ & $\mathrm{cv} \geq 65$ \\
\hline Bialystok & $\begin{array}{c}35.5 /-29.3 \\
7.4\end{array}$ & 291,660 & 7.5 & 2.0 & 5.6 & 3.8 & 2.1 \\
\hline Olsztyn & $\begin{array}{c}36.1 /-27.5 \\
7.7\end{array}$ & 172,467 & 6.7 & 0.7 & 3.0 & 2.0 & 0.9 \\
\hline Warsaw & $\begin{array}{c}36.4 /-21.6 \\
8.4\end{array}$ & $1,688,194$ & 10.3 & -2.1 & 46.7 & 34.2 & 18.4 \\
\hline
\end{tabular}

* - data from 1993-2002; ** - daily numbers of deaths in years 1993-1996 and 1999-2002.

A


B
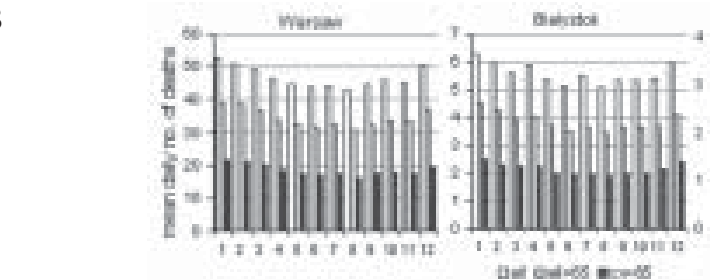

acas

ant ounes nowes

C
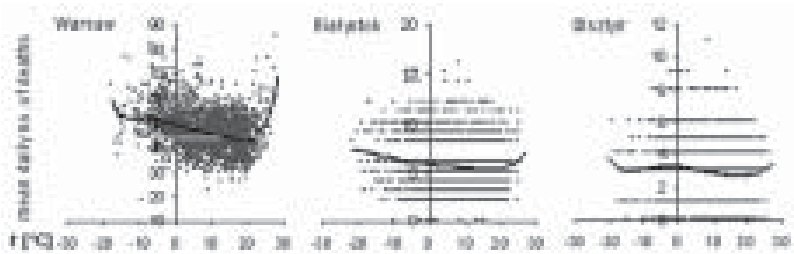

Figure 2. The age population structure (A), yearly course of mean daily numbers of deaths by selected causes (B) and the nonlinear relationship between mean daily air temperature and total mortality from all causes (1993-1996, 1999-2002) (C) in the 3 analyzed cities.

Polish heat waves are noted from May to August. In the north-east of the country more than $50 \%$ of them occur in July and $27 \%$ in August, while $23 \%$ start in May or June. In line with the definition accepted, the largest number of heat waves has been characteristic of Olsztyn, while the longest heat waves occurred in Bialystok and the hottest and most burdensome ones were in Warsaw (Table 2). Comparing with the means for Poland, it is thus clear that heat waves occur more often in the north-east than in the rest of the area. 
Table 2. The numbers, lengths and mean air temperatures of all heat waves and cold waves affecting the analyzed cities over the period 1993-2002.

\begin{tabular}{lccccccccccc}
\hline & \multicolumn{4}{c}{ city } & \multicolumn{3}{c}{ HEAT WAVES } & \multicolumn{6}{c}{ COLD WAVES } \\
\cline { 2 - 11 } & no. & mean & max. & $\mathrm{T}_{\max }$ & $\mathrm{T}_{\min }$ & no. & $\begin{array}{c}\text { mean } \\
\text { length }\end{array}$ & $\begin{array}{c}\text { max. } \\
\text { length }\end{array}$ & $\mathrm{T}_{\max }$ & $\mathrm{T}_{\min }$ \\
\hline Bialystok & 7 & 9.9 & 17 & 29.4 & 15.0 & 8 & 8.6 & 17 & -8.2 & -17.8 \\
Olsztyn & 10 & 7.5 & 15 & 28.8 & 14.7 & 6 & 9.3 & 14 & -7.0 & -17.1 \\
Warsaw & 9 & 7.6 & 16 & 30.1 & 16.7 & 7 & 10.4 & 24 & -6.4 & -14.5 \\
\hline mean - Poland & 7.1 & 8.9 & 21 & 29.3 & 15.6 & 6.4 & 9.8 & 24 & $?$ & $?$
\end{tabular}

A

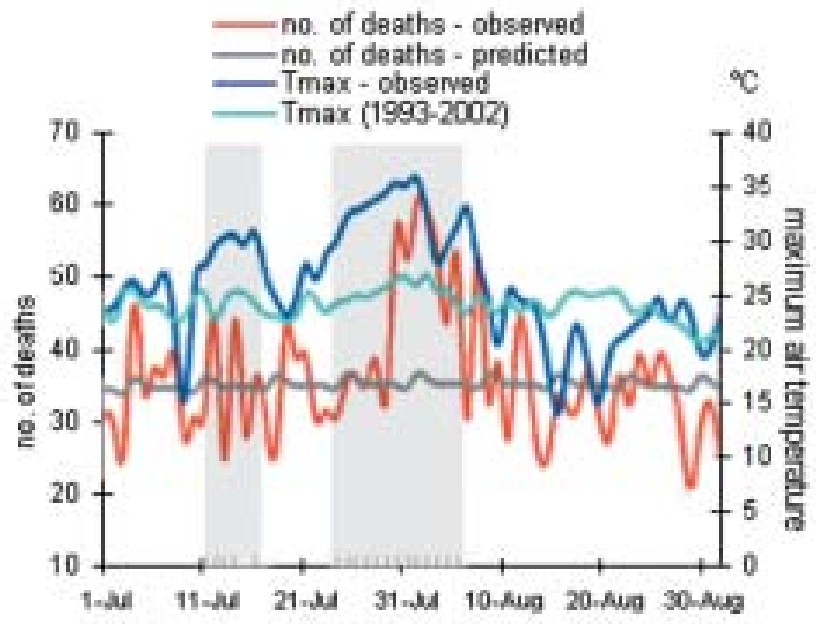

B

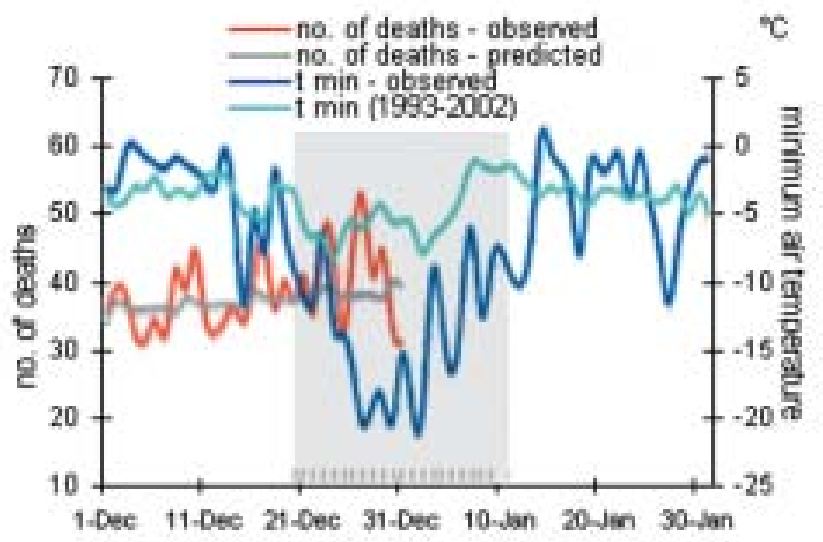

Figure 3. Daily deaths tolls (observed and predicted) during the heat wave in summer 1994 (A) and the cold wave in winter 1996/97 (B) in Warsaw. 
Table 3. Relative risk of death from all causes and from cardiovascular diseases among the elderly (aged 65 and over) during heat and cold waves. And lower and upper limits of $95 \%$ confidence intervals. Years 1993-1996 and 1999-2002.

\begin{tabular}{|c|c|c|c|c|c|c|c|c|}
\hline & \multicolumn{2}{|c|}{ Bialystok } & \multicolumn{2}{|c|}{ Olsztyn } & \multicolumn{2}{|c|}{ Warsaw } & \multicolumn{2}{|c|}{ Poland } \\
\hline & all & $\mathrm{cV}$ & all & $\mathrm{cV}$ & all & $\mathrm{cV}$ & all & $\mathrm{cV}$ \\
\hline \multicolumn{9}{|c|}{ Heat waVes } \\
\hline \multirow{2}{*}{ V-VI } & 1.04 & 1.01 & 0.94 & 1.11 & - & - & 1.15 & 1.18 \\
\hline & $\begin{array}{ll}0.71 \quad 1.53 \\
\end{array}$ &  & $\begin{array}{ll}0.61 \quad 1.44 \\
\end{array}$ & $\begin{array}{ll}0.64 & 1.94 \\
\end{array}$ & - & - & $\begin{array}{ll}1.07 & 1.23 \\
\end{array}$ & $\begin{array}{ll}1.08 & 1.28 \\
\end{array}$ \\
\hline \multirow{2}{*}{ VII } & 1.05 & 1.10 & 1.05 & 1.14 & 1.15 & 1.21 & 1.19 & 1.22 \\
\hline & $\begin{array}{ll}0.89 & 1.23 \\
\end{array}$ & $\begin{array}{ll}0.89 & 1.37 \\
\end{array}$ & $\begin{array}{ll}0.82 & 1.13 \\
\end{array}$ & $\begin{array}{ll}1.30 & 1.60 \\
\end{array}$ & $\begin{array}{ll}1.10 & 1.22 \\
\end{array}$ & $\begin{array}{ll}1.13 & 1.30 \\
\end{array}$ & $\begin{array}{ll}1.16 & 1.22 \\
\end{array}$ & $\begin{array}{ll}1.17 & 1.27 \\
\end{array}$ \\
\hline \multirow{2}{*}{ VIII } & 1.13 & 1.36 & 0.87 & 1.19 & 1.03 & 0.99 & 1.03 & 1.01 \\
\hline & $\begin{array}{ll}0.78 & 1.64 \\
\end{array}$ & $\begin{array}{ll}0.83 & 2.24 \\
\end{array}$ & $\begin{array}{ll}0.58 & 1.31 \\
\end{array}$ & $\begin{array}{ll}0.68 \quad 2.07 \\
\end{array}$ & $\begin{array}{ll}0.93 \quad 1.13 \\
\end{array}$ & $\begin{array}{ll}0.87 & 1.13 \\
\end{array}$ & $\begin{array}{ll}0.98 & 1.09 \\
\end{array}$ & $\begin{array}{ll}0.95 & 1.08 \\
\end{array}$ \\
\hline \multicolumn{9}{|c|}{ COLD WAVES } \\
\hline RR & 1.20 & 1.31 & 1.21 & 1.13 & 1.05 & 1.04 & 1.08 & 1.08 \\
\hline 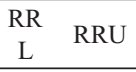 & $\begin{array}{ll}1.06 & 1.37\end{array}$ & 1.121 .54 & $0.99 \quad 1.48$ & $\begin{array}{ll}0.85 & 1.51\end{array}$ & $1.01 \quad 1.10$ & $0.98 \quad 1.10$ & $1.05 \quad 1.10$ & 1.05 \\
\hline
\end{tabular}

RR- relative risk, RRL - lower limit of $95 \%$ confidence interval, RRU - upper limit of $95 \%$ confidence interval, bold values - statistically significant at the 0.05 level.

During the analyzed period, the greatest heat wave occurred in summer 1994. Then, Bialystok suffered from the heat once $(25$ July -7 August), Olsztyn twice (11 - 16 July and 23 July - 6 August) and Warsaw three times (26 - 30 June, $10-17$ July and 23 July -7 August). The temperatures reached $35.5^{\circ} \mathrm{C}$ in Bialystok, $36.1^{\circ} \mathrm{C}$ in Olsztyn, and $36.4^{\circ} \mathrm{C}$ in Warsaw - exceptional values for Poland that were immediately reflected in a rise in numbers of deaths to between 50 and $230 \%$ above the expected level.

While in Bialystok and Olsztyn - despite the major percentage rises in mortality - the results were not statistically significant (because the value " 1 " appears in the range of the confidence interval), In Warsaw, the relative risk of death from all causes among people over 65 years of age was 1.33 (1.231.44 , with a $95 \%$ confidence interval), while that from cardiovascular disease was 1.37 (1.24-1.52) - statistically significant values relating to respective 33 and $37 \%$ rises in mortality during heat waves as compared to mild weather conditions. During the said heat wave in Warsaw there were an extra 132 deaths (77 from cardiovascular diseases) though considering the "harvesting effect", i.e. a compensatory decrease in overall mortality during the subsequent 30 days after a heat wave, the absolute number of heat wave-related deaths among the elderly reached 47 (Fig. 3A) (Kuchcik 2001, 2006; Kuchcik and Blażejczyk 2005).

In the coldest part of Poland (as represented by Bialystok and Olsztyn), heat waves generally generate only a non-significant rise in death rates, or even a decrease in mortality. Only in Warsaw during July heat waves is there a significant rise in deaths characterized by a narrow confidence interval and hence reinforcing the significance of this finding (Table 3).

While cold spells are noted from November to February, most of them start in December and are inclined to last until January - these are the longest and most severe periods of cold. Cold spells in the north-east of Poland are of greater duration than those elsewhere, $54 \%$ of them lasting 8 days and more (cf. $44 \%$ in Poland as a whole). The most frequent and severe cold periods are those noted in Bialystok, though the definition applied leaves the longest cold spell one that occurred in Warsaw and lasted from 20th December 1996 to 12th January 1997. During that particular period of cold weather, the minimum air temperature fell to $-29.3^{\circ} \mathrm{C}$ in Bialystok, $-23.5^{\circ} \mathrm{C}$ in Olsztyn and $-21.6^{\circ} \mathrm{C}$ in Warsaw, maximum air temperatures were 
respectively $-17.3^{\circ} \mathrm{C},-15.8^{\circ} \mathrm{C}$ and $-12.7^{\circ} \mathrm{C}$. The air pressure in all cities exceeded 1027 $\mathrm{hPa}$, the sky was cloudless and the air was extremely dry with water vapour pressure close to $1 \mathrm{hPa}$. The negative effect of such severe weather conditions was distinct, because the drop in temperature was immediately followed by an increase in numbers of deaths among the elderly. Regrettably, the period from the beginning of 1997 lacks data due to the physicians' strike, so there is no possibility of computing the influence of this special cold spell on the population (Fig. 3B).

When all cold spells were taken together, the mean relative risk of death in the metaanalysis was found to be positive in each city and for each cause of death. This means that cold spells are always unfavourable for human beings, and usually lead to a rise in mortality. In Bialystok during cold spells, the relative risk of death among elderly people is 1.20 from all causes and 1.31 from cardiovascular diseases - both results of major statistical significance, and the highest values calculated for Poland. In Olsztyn, the rise in mortality during cold spells is considerable, yet statistically non-significant. In Warsaw, only total mortality was associated with a significant if very small dependence on cold. Cold spells in the coldest part of Poland can thus be said to produce a greater rise in mortality than those in other regions (Table 3).

\section{CONCLUSIONS}

The research results presented here point to socioeconomic consequences of the climate changes observable in the Polish Lowland in recent decades. Extreme phenomena such as floods resulted in huge economic losses, especially in large and dense populated cities. Extreme heat exerts a strong influence in increasing risks of human mortality, mainly among the urban population in which a heat wave is intensified by urban heat island. In a heat wave both high temperatures during the day and high night-time temperatures resulting from night heat emissions ef- fect mainly the seniors, and this is a particular problem in an ageing society.

In general, in the north-east of Poland (where the climate is coldest and most continental), the impact of heat waves on mortality is found to be much more limited than elsewhere in the country (non-significant compared with a $19-22 \%$ rise calculated for the whole of Poland), while the impact of a cold spell is much greater (a rise in mortality up to $31 \%$ compared with the $8 \%$ average for Poland).

Extreme weather-related mortality assumes new significance when account is taken of the established climate changes in Europe, as well as the projections for the course of changes in future. For Poland in the period up to the end of the 21 st century, the climate models predict a rise in maximum air temperature of $4-6^{\circ} \mathrm{C}$ (compared with the period 1961-1990), and a rise in mean annual air temperature of at least $1.6^{\circ} \mathrm{C}$ as well as a maintained trend for greater rises in air temperature during the cold season (PRUDENCE). Heat waves are projected to become more frequent and more intense during the twenty-first century, such that every second summer may look like summer 2003 in south-west Europe. The example of such a scenario came to Poland in summer 2006, with its heat wave lasting almost one month, with 2 months of drought and flooding at the end. Thus annual excess summertime mortality is thought likely to increase, though reduced numbers of winter deaths caused by the decreased likelihood of cold spells may more than offset the increase in numbers of summer deaths. However, even in the presence of precisely-calculated indices for mortality during past situations, estimations of future impacts have to take account of one major unknown, i.e. whether or not the population will be able to adapt and acclimatise to changes in climate (WHO 2003).

This is especially true when account is taken of the last IPCC report (2007) indicating that eleven of the last twelve years (1995-2006) were among the 12 warmest years relative to global surface temperature since 1850 . And that trend of a warming cli- 
mate is even more marked than predicted in previous reports. Leaving aside the question of whether these climate changes are natural or anthropogenic, it is certain that in the coming years Polish society as a whole will be exposed to weather extremes and the wide range of associated consequences.

\section{ACKNOWLEDGEMENTS}

The research in the present paper has been carried out within the framework of the research project entitled "Extreme meteorological and hydrological events in Poland", financed by the Ministry of Science and Higher Education of Poland (PBZ-KBN086/P04/2003).

\section{REFERENCES}

Degórski, M. (1990), Warunki siedliskowe kateny ekosystemów leśnych na Wysoczyźnie Rawskiej, ze szczególnym uwzględnieniem dynamiki wodno-troficznych właściwości gleb [Habitat conditions in the forest ecosystems catena situated on the Rawa Plateau, with particular regard to the dynamics of hydrotrophic properties], Dokumentacja Geograficzna, 5-6, Warszawa.

ECA\&D (European Climate Assessment \& Dataset), available at <http://eca.knmi. $\mathrm{nl} /$ indicesextremes $>$.

IPCC (2007), Summary for Policymakers, in Solomon S., Qin, D., Manning, M., Chen, Z., Marquis, M., Averyt, K.B., Tignor, M., and Miller, H.L. (eds.), Climate Change 2007: The Physical Science Basis. Contribution of Working Group I to the Fourth Assessment Report of the Intergovernmental Panel on Climate Change, Cambridge University Press, Cambridge, United Kingdom and New York, NY, USA

Kalkstein, L.S. and Valimont, K. (1986), An evaluation of summer discomfort in the United States using a Relative Climatological Index, Bulletin of the American
Meteorological Society, 67, 7: 842-848.

Kosatsky, T. (2005), The 2003 European heat waves, Archives: Eurosurveillance monthly releases, 10, 7-8: 148-149.

Kozłowska-Szczęsna, T., Krawczyk, B. and Kuchcik, M. (2004), Wpływ środowiska atmosferycznego na zdrowie i samopoczucie człowieka [The influence of the atmospheric environment on human health and well-being], Monografie, IGiPZ PAN, 4, Warszawa.

Kuchcik, M. (2001), Mortality in Warsaw: is there any connection with weather and air pollution? Geographia Polonica 74, 1: 29-45.

Kuchcik, M. (2006), Fale upałów w Polsce w latach 1993-2002 [Heat waves in Poland over the period 1993-2002], Przeglad Geograficzny, 78, 3: 397-412.

Kuchcik, M. and Błażejczyk, K. 2005, Regional differentiation of heat waves in Poland and their impact on mortality. DWD, Annalen der Meteorologie, 41, 1: 415-418.

Kyselý, J. (2004), Mortality and displaced mortality during heat waves in the Czech Republic, International Journal of Biotemeteorology, 49, 2: 91-105.

Michelozzi, P., De Donato, F., Accetta, G., Forastiere, F., D'Ovidio, M., Perucci, C. and Kalkstein, L. S. (2004), Impact of heat waves on mortality - Rome, Italy June-August 2003, Morbidity and Mortality Weekly Report, 53, 17: 369-371.

PRUDENCE (Prediction of Regional scenarios and Uncertainties for Defining European Climate change risks and Effects), available at $<$ http://prudence.dmi.dk/ $>$.

Przybylak R., Vizi Z., Araźny A., Kejna M., Maszewski R. and Uscka-Kowalkowska J. (2006), Indeks ekstremalności klimatu Europy Środkowej w okresie 1951-2000 [The index of extremes of the climate of Central Europe in the period 1951-2000], in Gierszewski, P., Karasiewicz, T. (eds.), Idee i praktyczny uniwersalizm geografii - geografia fizyczna, Dokumentacja Geograficzna, 32: 240-248.

Sartor, F., Snacken, R., Demuth, C. and Walckiers, D. (1995), Temperature, ambient ozone levels, and mortality during sum- 
mer, 1994, in Belgium, Environmental Research, 70: 105-113.

Steadman, R.G. (1984), A universal scale of Apparent Temperature, Journal of Applied Meteorology, 23, 12: 1674-1687.

UNEP (United Nations Environment Programme) (2004), Impacts of the summer 2003 heatwave in Europe, <www.grid. unep.ch/product/publication/download/ ew_heat_wave.en.pdf. $>$.
WHO (2003), The health impacts of the 2003 summer heatwaves. Briefing note for the Delegations of the 53rd session of the WHO Regional Committee for Europe, pp.12, <http://www.euro.who.int/document/Gch/HEAT-WAVES\%20RC3.pdf $>$.

Paper first received: April 2007

In final form: March 2008 